\title{
Antioxidants in Fig (Ficus carica L.) and their effects in the prevention of atherosclerosis in hamsters
}

\author{
Manal Said Tawfik ${ }^{1, ~}$, Mona Alhejy ${ }^{2}$ \\ ${ }^{1}$ Department of Food Science and Technology, Faculty of Agriculture - Al Shtaby, Alexandria University, Alexandria, Egypt \\ ${ }^{2}$ Departemnt of Sciences and Medical Studies, King Saud University, Riyadh, Saudi Arabia
}

\section{Email address:}

mana92t@yahoo.com (M. S. Tawfik); mona.hejy@ksu.edu.sa (M. Alhejy)

\section{To cite this article:}

Manal Said Tawfik, Mona Alhejy. Antioxidants in Fig (Ficus carica L.) and their Effects in the Prevention of Atherosclerosis in Hamsters. Journal of Food and Nutrition Sciences. Vol. 2, No. 4, 2014, pp. 138-145. doi: 10.11648/j.jfns.20140204.17

\begin{abstract}
Phenolics are an important constituent of fruit quality because of their contribution to the taste, color and nutritional properties of fruit. This study aimed to determine the level of phenolics in fig. In addition, it is also to study their impact on early atherosclerosis. The used methodology was by feeding 30 hamsters which were grouped into three groups. Each group has equally of 10 hamsters. These three groups were fed standard diet, atherogenic diet, atherogenic diet with dried fig $(0.6 \mathrm{gm} / \mathrm{kg}$ body weight). During 8 weeks of this study trial, hamster body weight and its liver weight were measured. Subsequently, blood samples were collected for the following tests which are; total cholesterol level, High Density Lipoprotein Cholesterol (HLD), low Density Lipoprotein Cholesterol (LDL), Triglycerides (TG) and liver enzymes Aspartate amino transferase (AST), Alanine amino transferase (ALT). The analysed phenolics present at the highest content were gallic acid (30.99 mg per $100 \mathrm{~g} \mathrm{DW})$, followed by epigallocatechine $(25.44 \mathrm{mg}$ per $100 \mathrm{~g} \mathrm{DW})$, caffeine $(20.23 \mathrm{mg}$ per $100 \mathrm{~g} \mathrm{DW})$, catechine (13.88 mg per $100 \mathrm{~g} \mathrm{DW})$, epicatechine (12.48 mg per $100 \mathrm{~g} \mathrm{DW})$, rutin (3.26 mg per $100 \mathrm{~g}$ DW), epigallocatechine gallate $(2.52 \mathrm{mg}$ per $100 \mathrm{~g} \mathrm{DW})$. Significant increases in body weight and liver weight of hamsters fed atherogenic diet $(\mathrm{P}<0.05)$. On contrary, hamsters fed with fig diet they had insignificant decrease of body weight with significant decrease of their liver weight. Additionally, study has revealed significant increase of total cholesterol level, LDL, and TG among atherogenic diet group $(\mathrm{P}<0.05)$. While hamster group fed with fig in diet showed a significantly decreased in the total cholesterol level, LDL, and TG. The HDL level was improved in the former group. However, liver enzymes (AST), (ALT) were increased significantly among group which was fed by atherogenic diet. But they were significantly decreased $(\mathrm{P}<0.05)$ among those hamsters fed by fig.
\end{abstract}

Keywords: Atherosclerosis, Antioxidants, Phenols, Fig, Total Cholesterol, HDL, LDL, TG, Liver Enzymes

\section{Introduction}

There is a growing interest in the health benefits of phenols and flavonoids found in fruits and vegetables, which are rich natural resources of theirs. The epidemiological studies indicated that the consumption of these foods is likely to be linked to a lower risk of cardiovascular [1] and cancer [2].

The vulnerability of the body's cells to elevated concentrations of oxidizing agents and free radicals leads to the oxidation of amino acids, lipids and accelerate the demolitions in the case of cell death and tissue damage [3] leading to the emergence of many diseases such as cancer, heart disease, blood vessels, hardening of the arteries, liver disorders, aging, high blood pressure, complications of diabetes and other diseases [4].
Fruits and vegetables contain a wide range of antioxidant compounds including phenolic compounds, vitamins and include phenolic compounds on: anthocyanins, flavan-3-ols, flavonols, hydroxycinnamates [5].

Eating fruits and vegetables leads to increased levels of antioxidants in the blood serum, which may be considered one of the factors to prevent heart disease [6,7]. In the previous study it is confirmed that the spread of diseases and epidemics on the existence of a direct inverse relationship between eating at least five servings of fruits and vegetables and low incidence of chronic diseases, i.e. heart disease [8].

Figs (Ficus carica L.) are a widespread species commonly grown, especially in warm, dry climates. The 
ideal condition for intensive cultivation of figs is a semidried climate with irrigation. The world production of figs is about one million tons, and it is mostly concentrated in the Mediterranean. In this area, figs have been grown for centuries and are the most frequently mentioned fruit in the Bible [9].

Figs are widely consumed fresh, either peeled or not. Fresh fruits naturally have a short, post-harvest life of $7-$ 10 days, but with a combination of cooler conditions and a $\mathrm{CO} 2$-enriched atmosphere, the fruit can be stored for up to 2-4 weeks [10]. Figs are also very popular as dried fruit, since drying prolongs their storability.

As a seasonal food, figs represent an important constituent of the Mediterranean diet [11]. This type of diet is considered one of the healthiest and is associated with longevity [12]. Figs are an excellent source of minerals, vitamins and dietary fibre; they are fat and cholesterol-free and contain a high number of amino acids $[9,11]$. Similarly to other fruit species, figs contain sugars and organic acids that influence their quality. They also contain phenolic substances, which contribute importantly to their quality; especially because it has been proven that their consumption can have a positive effect on human health. The content level of phenolics is usually influenced not only by the cultivar, but also varies significantly from one fruit part to the other; moreover, it is heavily dependent on the growing technology in the orchard [13]. Although figs are an important fresh fruit variety in many countries, as well as a delicious dried fruit consumed in most parts of the world, there are only a few reports dealing with the phenolic contents of these fruit [14].

The figs are a good source of flavonoids and phenols compounds have been found in numerous studies that eating one of two medium-sized dried figs equivalent (40 g) resulted in a significant increase in antioxidant capacity [15].

Studies conducted in various countries and on various human aggregates showed clear and consistent inverse relationship between the quantity of intake of vegetables, fruits and chronic diseases, chronic disease such as coronary artery disease Cardiovascular disease (CVD) and oncology [16].

Researchers and food manufacturers showed interested in growing phenols numerous and was the main reason for this interest is to recognize the characteristics of antioxidants in phenols numerous and well provided large in our diet and their potential role in the prevention of various diseases associated with Baltaxd such as cancers, heart disease, blood vessels and nerves [17].

There are many fruits rich in content of antioxidants, such as cherries, peaches, kiwi, red grapes, strawberries, cranberries, figs, dates [18].

Ficus species are rich source of naturally occurring antioxidants of which phenolic compounds and flavanoids play a vital role in preventing innumerable health disorders related to oxidative stress including cardiovascular diseases [19].
Free radicals are a major cause of atherosclerosis. The study indicated that antioxidants play a role in the oxidation of free radicals and thus the prevention of atherosclerosis, so it was the goal of the study to know the effect of antioxidants in the prevention of atherosclerosis.

Therefore, the aim of this study is to estimate the proportions of total phenols in one class for figs common consumption in Arab area and to identify the types and their impact on the indicators of atherosclerosis by biochemical estimates in the blood; total cholesterol level, high density lipoprotein cholesterol (HLD), low density lipoprotein cholesterol (LDL), triglycerides (TG) and liver enzymes; aspartate amino transferase (AST), alanine amino transferase (ALT) in hamesters.

\section{Materials and Methods}

\subsection{Figs}

Figs chosen with purple color has the scientific name Ficus carica were obtained from the Tabuk region in (Tabuk Agricultural Development).

\subsection{Chemicals}

All chemicals were obtained from sigma chemical composition, ST. Louis, MO.USA.

\subsection{Drying of Figs}

Figs were chosen full maturity, washed it well and then put it in boiling water for 30 seconds, cut halves and flooded in a solution of citric acid $(5 \mathrm{~g} / \mathrm{L})$ for 10 minutes and then rinsed with cold water and left for 24 hours until dried completely. Figs were arranged in a tray drying single layer and put in a drying oven at a temperature of $60^{\circ} \mathrm{C}$ for 24 hours after that it has been milled to be ready for analysis and added to the diet [20].

\subsection{Extraction of Total Phenols}

$100 \mathrm{~g}$ of dried figs was extracted with $300 \mathrm{ml}$ of extraction solution (water: methanol) (4:1) by mixing in blender for 3 minutes, then shaking the solution for 5 hours by orbital shaker at a temperature of $20^{\circ} \mathrm{C}$. The extracted was centrifuged at a fast 4,000 rpm for 10 minutes, then rid of the amount of methanol in the extract by using a rotary evaporator (Rotary evaporator, BIBBY, Model RF200B). The sample was stored in opaque glass tray in the freezer until use [21].

\subsection{Total Phenolic Content (TPC)}

The TPC was estimated using the Folin-Ciocalteu colorimetric method [22]. The extracted sample equal to volume of $0.4 \mathrm{ml}$ was oxidized with $2 \mathrm{ml}$ of $0.5 \mathrm{~mol} / \mathrm{L}$ Folin-Ciocalteu reagent for $4 \mathrm{~min}$ at room temperature. Then the reaction was neutralized with $2 \mathrm{ml}$ of $75 \mathrm{mg} / \mathrm{ml}$ saturated sodium carbonate. The absorbance was measured at $760 \mathrm{~nm}$ after incubation for $2 \mathrm{~h}$ at room temperature in 
the dark. Quantification was done on the basis of the standard curve of gallic acid $(10,20,30,40,50$, and 60 $\mathrm{mg} / \mathrm{L})$. Results were expressed as gallic acid equivalent (GAE), i.e., mg gallic acid/g DW.

\subsection{Phenolic Composition by Reversed Phase (RP)-HPLC}

RP-HPLC analysis was performed using a Shimadzu HPLC system (LC-10A series, Tokyo, Japan), consisting of a binary pump and a diode-array detector (DAD), and equipped with a Shim-pack RP-C18 column (5 $\mu \mathrm{m}, 250$ $\mathrm{mm} \times 4.6 \mathrm{~mm}$ ) (Shimadzu Co., Japan). Sample preparation for HPLC analysis was as follows: the figs extract was centrifuged at $10000 \mathrm{r} / \mathrm{min}$ for $15 \mathrm{~min}$, filtered using a Millipore filter $(0.22 \mu \mathrm{m}$ nylon membrane $)$ at room temperature, and then injected into HPLC for analysis. Phenolic compounds in the samples were analyzed at $35^{\circ} \mathrm{C}$ with the mobile phase (solution A, $0.1 \%$ formic acid, and solution $\mathrm{B}, 100 \%$ methanol). The flow rate was $0.8 \mathrm{ml} / \mathrm{min}$ and the injection volume was $10 \mu \mathrm{l}$. Detection was monitored at $280 \mathrm{~nm}$ [23].

\subsection{Experimental Animals}

Thirty rats (male) type of Hamster were chosen. Hamsters represent an useful test system because when fed a fat-rich diet they develop dyslipidemia and atherosclerotic plaques, similar in many respects to human atheroma [24] ranging from weight $114 \pm 10 \mathrm{~g}$ were obtained from the Department of Pharmacology (KSU). The experiment was conducted in the house of the animal at King Khalid University (Faculty of Medicine, King Saud University). Hamsters were handled according to the guidelines of the Committee on Animal Care at the University of Montpellier and NIH guidelines [25].

Experiment was conducted for a period of 8 weeks with creating the right conditions for the rats where placed individually in plastic cages and the temperature was in the house of the animal $24^{\circ} \mathrm{C}$ and moisture relative $50-65 \%$ and cycle lighting/ blackouts(12-hour). Food and water was available throughout the period of the experiment rats with changing the water daily. Rats were weighed once a week, as has been calculated daily food intake during the period of the experiment.

They were randomly assigned to three groups of 10 not statistically different for weight. For 8 weeks all the hamsters were fed a atherogenic diet consisting of casein (200 g/kg), 1-methionine (3 g/ $/ \mathrm{kg})$, corn starch (393 g/ $/ \mathrm{kg})$, sucrose $(154 \mathrm{~g} / \mathrm{kg})$, cellulose $(50 \mathrm{~g} / \mathrm{kg})$, lard $(150 \mathrm{~g} / \mathrm{kg})$, and cholesterol $(5 \mathrm{~g} / \mathrm{kg})$ [24]. The diet also contained vitamin $(10 \mathrm{~g} / \mathrm{kg})$ and mineral mixes $(35 \mathrm{~g} / \mathrm{kg})$. It was formulated according to AIN-93 guidelines [26] and was devoid of selenium, vitamin $\mathrm{C}$ and vitamin E. During the 8-week period, the hamsters received either reference diet [27] (group 1), atherogenic diet (group 2), atherogenic diet with dried fig (group 3) (table 1). Dried fig fed was adjusted daily to the weight of hamsters. The calculation is based on a consumption of two medium-sized dried figs equivalent
(40 g/day for a $70 \mathrm{~kg}$ human) [15].

Table 1. Experimental groups of hamsters used in the experiment

\begin{tabular}{ll}
\hline Groups & Types of food intake \\
\hline Group 1 & Reference diet \\
Group 2 & Atherogenic diet \\
Group 3 & Atherogenic diet $+(0.6 \mathrm{~g} / \mathrm{kg}$ of body weight of dried figs $)$ \\
\hline
\end{tabular}

\subsection{Weight Gain and Relative Liver Weight}

Weight gain of rats was calculated on the basis of the increase in the weight of the rat during the period of the experiment, according to the following equation:

\section{Weight gain = weight of slaughter rat - rat weight at the} beginning of the experiment [28].

Relative liver weight was calculated from the following equation:

Relative liver weight $=($ liver weight $(\mathrm{g}) /$ body weight

$$
(\mathrm{g})) \times 100 \text {. }
$$

\subsection{Biochemical Estimates in Blood Serum}

At the end of the experiment after 8 weeks rats drugged by diethyl ether, and the withdrawal of blood in a manner twitching of orbital sinus in tubes containing the material proof of a blood clot and save serum in plastic tubes sealed and saved at a temperature of $4{ }^{\circ} \mathrm{C}$ until conducting analysis As eradicated rat livers and washed in a solution $(0.85 \%$ sodium chloride) and then dried between filter papers and then weighed directly.

\subsubsection{Separation of the Samples}

After the withdrawal of blood samples from rats centrifuge were used to separate the samples at a speed of $5000 \mathrm{rev} / \mathrm{min}$ for 10 minutes, then placed in Eppendorf tubes and kept at $2-8^{\circ} \mathrm{C}$, then estimate the samples.

\subsubsection{Estimate the Level of Total Cholesterol}

Total cholesterol was estimated in the blood serum according to method of Richmond [29]. Randox ${ }^{\circledR}$ cholesrol enzymatic colorimetric kit was used (Randox ${ }^{\circledR}$; Cholesterol Enzymatic Kit. No. 290). The Absorbance measured by a spectrophotometer at wavelength of $500 \mathrm{~nm}$. The total cholesterol concentration; expressed as $\mathrm{mg} / 100$ $\mathrm{ml}$, was calculated according to the following equation:

Concentration of total cholesterol $(\mathrm{mg} / 100 \mathrm{ml})=\left(A b_{500}\right.$ of the sample/ $A b_{500}$ of cholesterol standard $) \times$ concentration of cholesterol standard.

\subsubsection{Estimate of Triglycerides}

Triglycerides were estimated in blood serum by using enzymatic colorimetric method using the triglycerides detector brand Randox ${ }^{\circledR}$ (Randox; Triglycerides Enzymatic Kit. No 210 - Antrim) according to the method of Trinder 
[30]. Absorbance was measured by a spectrophotometer at wavelength $500 \mathrm{~nm}$ and the concentration of triglycerides was calculated by $\mathrm{mg} / 100 \mathrm{ml}$ according to the following equation:

Concentration of triglycerides $(\mathrm{mg} / 100 \mathrm{ml})=\left(A b_{500}\right.$ of the sample / $A b_{500}$ of standard triglycerides $) \times$ concentration of standard triglyceride.

\subsubsection{Estimate HDL Cholesterol}

High-density lipoproteins (HDL) cholesterol was estimated according to the method of Richmond [29] in the blood serum by deposition of all other lipoproteins, centrifugation to get HDL cholesterol, then estimated HDL cholesterol in the same way as much as it has been used for total cholesterol. Randox ${ }^{\circledR}$; HDL cholesterol precipitant Kit. No. 204 was used. The concentration of HDL was calculated by $\mathrm{mg} / 100 \mathrm{ml}$ according to the following equation:

Concentration of HDL cholesterol $(\mathrm{mg} / 100 \mathrm{ml})=\left(A b_{500}\right.$ of the sample $/ A b_{500}$ of cholesterol standard $) \times$ concentration of cholesterol standard.

\subsubsection{Estimate Low-Density Lipoproteins Cholesterol}

Low-density lipoproteins cholesterol was estimated according to the information available from other fat according to the method of Van Horn et al. [31] by using the following equations:

VLDL cholesterol $(\mathrm{mg} / 100 \mathrm{ml})=$ triglycerides $/ 5$

LDL cholesterol $(\mathrm{mg} / 100 \mathrm{ml})=$ total cholesterol $-(\mathrm{HDL}$ cholesterol + VLDL cholesterol).

\subsubsection{Assay of Serum Aspartate Amino Transaminase (AST) Activity}

The assay of aspartate amino transaminase (AST) activity was carried out by the method of Reitman and Frankel [32]. The method is based on the principle that oxaloacetate (oxaloacetic acid) that is formed from the aspartate aminotransferase catalysed reaction between alpha ketoglutarate and aspartate is coupled with chromogen (2,4-dinitrophenyl hydrazine) in alkaline medium to form colored hydrazone. The concentration of the colored hydrazone is proportional to the aspartate aminotransferase activity and is measured with a colorimeter. To $0.05 \mathrm{ml}$ of each serum sample in a test tube was added $0.25 \mathrm{ml}$ of buffer/substrate solution. The content was incubated at $37^{\circ} \mathrm{C}$ for $60 \mathrm{~min}$ in a water bath followed by the addition of $0.25 \mathrm{ml}$ of chromogen solution. The content was mixed and allowed to stand for $20 \mathrm{~min}$ at room temperature after which $2.5 \mathrm{ml}$ of sodium hydroxide $(0.4 \mathrm{~N})$ was added and mixed. The absorbance was read after $5 \mathrm{~min}$ against blank at $540 \mathrm{~nm}$. The blanks were treated as the samples but without the addition of chromogen solution used to stop all enzymatic reactions. AST activity (IU/L) was read off from the standard curve.

\subsubsection{Determination of Serum Alkaline Aminotransferase (ALT) Activity}

The serum alkaline aminotransferase (ALT) activity was assayed by the method of Reitman and Frankel [32]. The method is based on the principle that pyruvate (pyruvic acid) formed from the alanine aminotransferase catalysed reaction between $\alpha$-ketoglutarate (oxoglutarate) and Lalanine is coupled with chromogen solution (2, 4dinitrophenyl hydrazine) in an alkaline medium to form colored hydrazone, the concentration of which is proportional to the alanine aminotransferase activity as measured with a colorimeter. To $0.05 \mathrm{ml}$ of each serum sample in a test tube was added $0.25 \mathrm{ml}$ of buffer/substrate solution. This was incubated at $37^{\circ} \mathrm{C}$ for $30 \mathrm{~min}$ in a water bath followed by the addition of $0.25 \mathrm{ml}$ of chromogen solution. The content was mixed and allowed to stand for $20 \mathrm{~min}$ at room temperature. Then $2.5 \mathrm{ml}$ of sodium hydroxide $(0.4 \mathrm{~N})$ was added and mixed. The absorbance was read after 5 min against the blank at $540 \mathrm{~nm}$. The blanks were treated as the samples but without the addition of chromogen solution used to stop all the enzymatic reactions. ALT activity (IU/L) was read off from the standard curve.

\subsection{Statistical Analysis}

Statistical analysis was performed for the results obtained by analyzing the significance differences and the differences unidirectional (On way ANOVA). Results expressed as averages \pm standard error (SD), and the difference was considered significant when $(\mathrm{P}<0.05)$ (Steel and Torrie, 1980).

\section{Results and Discussion}

\subsection{Amount and Types of Total Phenols in Figs}

Phenolic acids and flavonoids have an even stronger antioxidant activity than, for instance, ascorbic acid [33]. Besides antioxidant effects, phenolic compounds possess a wide spectrum of biochemical properties and can also have a beneficial effect in preventing the development of diseases like cancer and cardiovascular diseases [34].

Table (2) showed the content of phenols compounds, the types and amount of phenolic compounds of fig on the basis of dry weight. The amount of total phenols compounds in the fruits of the fig was $345.26 \mathrm{mg} / 100 \mathrm{~g}$ dry weight.

When comparing the content of total phenols in figs in this study with the study [35] who studied three varieties of dried figs included Turkish, Dama, and Spanish in different seasons, and the result was that total phenols in three varieties $(19,2,19.1,17.8 \mathrm{mg} / 100 \mathrm{~g})$ respectively, and this is contrary to the current study, and this may be due to differences in season and type of user figs. The content of phenolic compounds was Quercetin (10.2, 13.0, 10.9 $\mathrm{mg} / 100 \mathrm{~g}$ ) respectively, while the compound Kaempferol (2, $10,20 \mathrm{mg} / 100 \mathrm{~g})$ respectively. The difference of the 
current study may be due to differences in season, the region of agriculture and the type of figs used.

The types of phenolic compounds, which were separated by a HPLC were 11 compounds: gallic acid (30.99 $\mathrm{mg} / 100 \mathrm{~g} \mathrm{DW})$, epigallocatechine (25.44 mg/100g DW), caffeine $(20.23 \mathrm{mg} / 100 \mathrm{~g} \mathrm{DW})$, catechine $(13.88 \mathrm{mg} / 100 \mathrm{~g}$ DW), epicatechine $(12.48 \mathrm{mg} / 100 \mathrm{~g} \mathrm{DW})$, rutin $(3.26$ $\mathrm{mg} / 100 \mathrm{~g} \mathrm{DW})$, epigallocatechine gallate $(2.52 \mathrm{mg} / 100 \mathrm{~g}$ $\mathrm{DW})$, epigcatechine gallate $(0.85 \mathrm{mg} / 100 \mathrm{~g} \mathrm{DW})$, quercetin $(0.56 \mathrm{mg} / 100 \mathrm{~g} \mathrm{DW})$, isorahmentin $(0.29 \mathrm{mg} / 100 \mathrm{~g} \mathrm{DW})$, and kaempferol (0.12 mg/100g DW) (Table 2).

Table 2. Concentration of phenolic compounds in fig ( $\mathrm{mg} / 100 \mathrm{~g}$ dry weight)

\begin{tabular}{ll}
\hline Compounds & mg/100g dry weight \\
\hline Total Phenols & $345.26 \pm 5.6$ \\
Gallic acid & $30.99 \pm 2.5$ \\
Epigallocatechine & $25.44 \pm 1.8$ \\
Catechine & $13.88 \pm 3.1$ \\
Caffeine & $20.23 \pm 2.1$ \\
Epicatechine & $12.48 \pm 1.6$ \\
Epigallocatechine gallate & $2.52 \pm 0.5$ \\
Epicatechine gallate & $0.85 \pm 0.4$ \\
Rutin & $3.26 \pm 1.3$ \\
Quercetin & $0.56 \pm 0.7$ \\
Kaempferol & $0.12 \pm 0.05$ \\
Isorahmentin & $0.29 \pm 0.07$ \\
\hline
\end{tabular}

*Expressed as mg gallic acid.

The highest amounts were exhibited in the case of gallic acid, followed by epigallocatechine, with small amounts of isorahmentin and kaempferol.

Gallic acid and its glycosides are characteristic of some berry crops, like raspberry or strawberry, in similar or higher amounts in strawberry than for figs [36]. It has been proven that grape seeds and skins are good sources of gallic acid; the seeds contain especially high values [37]. Amounts of gallic acid comparable to the data achieved for figs were also identified in some tropical fruit and persimmon [38]. Gallic acid is extremely well absorbed into the human body, compared with other polyphenols [17]. In the review [39] gallic acid was shown to have a positive effect under in vitro conditions against cancer cells.

Both epicatechin and catechin belong to the group of catechins. Authors [40] report that this is a very important group of compounds in the Mediterranean diet. However, according to the data presented, figs do not belong to fruit rich in both constituents, in comparison to plums, apples or various kinds of berries. Figs analysed in our study contained more catechin than epicatechin.

Phenols in dried fruit may be important antioxidants as demonstrated by the in vivo antioxidant effect from eating a serving size of figs. Therefore, more dried fruits should be recommended to be added to the diet by dieticians and nutritionists [15].

Veberic et al. [14] evaluated the phenolic profile of fig fruit commonly grown in Slovenia's coastal region. The analysed phenolics present at the highest content were rutin (up to $28.7 \mathrm{mg}$ per $100 \mathrm{~g} \mathrm{FW}$ ), followed by catechin (up to $4.03 \mathrm{mg}$ per $100 \mathrm{~g} \mathrm{FW}$ ), chlorogenic acid (up to $1.71 \mathrm{mg}$ per $100 \mathrm{~g} \mathrm{FW}$ ), epicatechin (up to $0.97 \mathrm{mg}$ per $100 \mathrm{~g} \mathrm{FW}$ ), gallic acid (up to $0.38 \mathrm{mg}$ per $100 \mathrm{~g} \mathrm{FW}$ ) and, finally, syringic acid (up to $0.10 \mathrm{mg}$ per $100 \mathrm{~g} \mathrm{FW}$ ). The difference in the results may be due to differences in season, the region of agriculture and the type of figs used.

\subsection{The Effect of Eating Figs on Weight Gain and Relative Liver Weight in Hamster}

Table (3) indicate weight gain and relative liver weight of hamster in different groups at the end of the experiment ( 8 weeks) and the impact of the hamster eating high- fat diet, as well as eating figs in the other diets.

Table 3. Measurements of body weight gain ( $g$ ) and relative liver weight ( $g$ ) of hamsters in different groups after 8 weeks

\begin{tabular}{lll}
\hline Groups & Weight gain (gm) & Relative liver weight (gm) \\
\hline Group 1 & $1.9 \pm 0.3^{\mathrm{a}}$ & $4.2 \pm 0.4^{\mathrm{a}}$ \\
Group 2 & $2.7 \pm 0.6^{\mathrm{b}}$ & $6.3 \pm 0.3^{\mathrm{b}}$ \\
Group 3 & $2.3 \pm 0.5^{\mathrm{b}}$ & $5.7 \pm 0.4^{\mathrm{c}}$ \\
\hline
\end{tabular}

Average \pm standard error.

Averages, which carry a small English letters (a, b, c) are similar in the same column means the absence of significant differences $(\mathrm{P}>0.05)$.

It was observed that there is an significant increase (P $<0.05)$ in the weight of hamster, which fed with atherogenic $\operatorname{diet}(2.7 \mathrm{~g})$ and the group that fed with atherogenic diet and figs has less weight but are not significantly $(2.3 \mathrm{~g})$, compared to the group that fed with atherogenic diet, but for the relative weight of the liver there was a significant rise $(\mathrm{P}<0.05)$ in the case of hamster which fed with atherogenic diet $(6.3 \mathrm{~g})$ and there was a significant decline in the case of hamster which fed with atherogenic diet and figs $(5.7 \mathrm{~g})$.

\subsection{Measurements of Total Cholesterol and High-Density Cholesterol (HDL) and Low-Density Cholesterol (LDL) and Triglyceride (TG)}

Tables $(4,5,6,7)$ respectively showed the level of total cholesterol $(\mathrm{mg} / \mathrm{dl})$, triglyceride level $(\mathrm{mg} / \mathrm{dl})$, the level of HDL (mg/dl) and the level of LDL (mg/dl) for groups of hamster that fed with three types of diets and the effect of eating figs by $(0.6 \mathrm{~g} / \mathrm{kg}$ of body we after 4 weeks and 8 weeks.

Table 4. The effect of figs on the level of total cholesterol $(\mathrm{mg} / \mathrm{dl})$ for different groups of hamsters after 4 weeks and 8 weeks

\begin{tabular}{llll}
\hline Groups & $\begin{array}{l}\text { Beginning of the } \\
\text { experiment }\end{array}$ & After 4 weeks & After 8 weeks \\
\hline Group 1 & $204.12 \pm 9.3^{\mathrm{aA}}$ & $208.18 \pm 1.4^{\mathrm{aA}}$ & $207.02 \pm 3.4^{\mathrm{aA}}$ \\
Group 2 & $206.10 \pm 7.1^{\mathrm{aA}}$ & $213.9 \pm 2.3^{\mathrm{bB}}$ & $216.4 \pm 3.7^{\mathrm{bC}}$ \\
Group 3 & $194.94 \pm 4.3^{\mathrm{aA}}$ & $186.96 \pm 2.1^{\mathrm{cB}}$ & $183.76 \pm 4.9^{\mathrm{cB}}$ \\
\hline
\end{tabular}

Average \pm standard error

Averages carrying letters English small $(\mathrm{a}, \mathrm{b}, \mathrm{c})$ are similar in the same column mean significant differences $(\mathrm{P}<0.05)$, averages that carry letters English large (A, B, C) are similar in the same row means no differences significantly $(\mathrm{P}>0.05)$. 
Table 5. The effect of eating figs on the level of triglycerides ( $\mathrm{mg} / \mathrm{dl})$ for the different groups of hamsters after 4 weeks and 8 weeks

\begin{tabular}{llll}
\hline Groups & $\begin{array}{l}\text { Beginning of the } \\
\text { experiment }\end{array}$ & After 4 weeks & After 8 weeks \\
\hline Group 1 & $182.6 \pm 5.1^{\mathrm{aA}}$ & $183.4 \pm 2.2^{\mathrm{aA}}$ & $184.1 \pm 3.4^{\mathrm{aA}}$ \\
Group 2 & $184.5 \pm 3.7^{\mathrm{aA}}$ & $192.0 \pm 3.4^{\mathrm{bB}}$ & $198.5 \pm 6.7^{\mathrm{bB}}$ \\
Group 3 & $181.2 \pm 6.1^{\mathrm{aA}}$ & $158.8 \pm 7.8^{\mathrm{cB}}$ & $151.3 \pm 5.6^{\mathrm{BB}}$ \\
\hline
\end{tabular}

Average \pm standard error

Averages carrying letters English small $(a, b, c)$ are similar in the same column mean significant differences $(\mathrm{P}<0.05)$, averages that carry letters English large (A, B, C) are similar in the same row means no differences significantly $(\mathrm{P}>0.05)$.

Table 6. The effect of eating figs on the level of HDL ( $\mathrm{mg} / \mathrm{dl})$ for the different groups of hamsters after 4 weeks and 8 weeks

\begin{tabular}{llll}
\hline Groups & $\begin{array}{l}\text { Beginning of the } \\
\text { experiment }\end{array}$ & After 4 weeks & After 8 weeks \\
\hline Group 1 & $69.2 \pm 5.1^{\mathrm{aA}}$ & $74.2 \pm 3.1^{\mathrm{aA}}$ & $72.6 \pm 2.4^{\mathrm{aA}}$ \\
\hline Group 2 & $68.6 \pm 4.1^{\mathrm{aA}}$ & $66.5 \pm 2.7^{\mathrm{bA}}$ & $63.6 \pm 1.7^{\mathrm{bB}}$ \\
\hline Group 3 & $63.5 \pm 2.5^{\mathrm{aA}}$ & $68.2 \pm 3.4^{\mathrm{cB}}$ & $77.5 \pm 1.4^{\mathrm{cC}}$ \\
\hline
\end{tabular}

Average \pm standard error

Averages carrying letters English small $(\mathrm{a}, \mathrm{b}, \mathrm{c})$ are similar in the same column mean significant differences $(\mathrm{P}<0.05)$, averages that carry letters English large (A, B, C) are similar in the same row means no differences significantly $(\mathrm{P}>0.05)$.

Table 7. The effect of eating figs on the level of $L D L(\mathrm{mg} / \mathrm{dl})$ for the different groups of hamsters after 4 weeks and 8 weeks

\begin{tabular}{llll}
\hline Groups & $\begin{array}{l}\text { Beginning of the } \\
\text { experiment }\end{array}$ & After 4 weeks & After 8 weeks \\
\hline Group 1 & $98.4 \pm 5.8^{\mathrm{aA}}$ & $97.3 \pm 2.4^{\mathrm{aA}}$ & $97.6 \pm 3.4^{\mathrm{aA}}$ \\
Group 2 & $100.6 \pm 5.1^{\mathrm{aA}}$ & $109.0 \pm 3.2^{\mathrm{bB}}$ & $113.1 \pm 2.4^{\mathrm{bC}}$ \\
Group 3 & $95.2 \pm 6.1^{\mathrm{aA}}$ & $87.0 \pm 1.6^{\mathrm{cB}}$ & $86.0 \pm 3.5^{\mathrm{cB}}$ \\
\hline
\end{tabular}

Average \pm standard error

Averages carrying letters English small $(\mathrm{a}, \mathrm{b}, \mathrm{c})$ are similar in the same column mean significant differences $(\mathrm{P}<0.05)$, averages that carry letters English large (A, B, C) are similar in the same row means no differences significantly $(\mathrm{P}>0.05)$.

Table (4) showed that the decline in the level of total cholesterol had a significant effect $(\mathrm{P}<0.05)$ after 8 weeks $(183.76 \mathrm{mg} / \mathrm{dl})$ more than 4 weeks from the beginning of the experiment $(186.96 \mathrm{mg} / \mathrm{dl})$ in the case of group fed with figs.

Table (5) showed a significant decrease in the level of triglycerides after 4 weeks $(158.8 \mathrm{mg} / \mathrm{dl})$ of hamster which fed with the diet containing figs but not significant after 8 weeks (153.3 mg/dl).

In table (6) there was a significant improvement in the level of HDL after 4 weeks in the case of hamster fed the diet containing figs $(68.2 \mathrm{mg} / \mathrm{dl})$.

In Table (7) observed a significant decline in the level of LDL after 4 weeks from the beginning of the experiment in the case of hamster which fed with diet containing figs (87 $\mathrm{mg} / \mathrm{dl})$ and did not change significantly after 8 weeks $(86$ $\mathrm{mg} / \mathrm{dl}$ ), and the increase in LDL was more significant after 4 weeks $(109 \mathrm{mg} / \mathrm{dl})$ and after 8 weeks $(113.1 \mathrm{mg} / \mathrm{dl})$ in the case of hamster which fed with atherogenic diet only.

Phenols and flavonoid compounds have the feature of higher antioxidant than vitamins and that recognized when measured as a disincentive for the oxidation of low-density lipoprotein LDL, which is an indicator of atherosclerotic disease [41].

Fig antioxidants can enrich lipoproteins in plasma and protect them from subsequent oxidation [15].

Abundant evidence exists for a beneficial effect of phenol antioxidants (this includes monophenols and polyphenols) on heart disease and cancer. It is hypothesized that phenol antioxidants are the agents in fruits that are at least partly responsible for these protective effects. An early step in atherosclerotic lesion formation is oxidation of low (LDL) and very low (VLDL) density lipoproteins [42].

\subsection{Measuring the Activity of Liver Enzymes ALT \& AST}

Tables $(8,9)$ noted the level of enzyme activity ALT, AST, respectively, to groups of hamster that fed with different types of diets and the effect of eating figs at the beginning of the experiment and after 4 weeks and 8 weeks of eating diets.

Table (8) noted a significant decrease in the level of activity of the enzyme ALT after 4 weeks in hamster which fed diet containing figs (52 IU/L) and this decrease was significant after 8 weeks (44 IU/L).

In the table (9) The decrease in the level of activity of the enzyme AST was significant effect after 4 weeks in the case of hamster, which fed with the diet containing figs (43 $\mathrm{IU} / \mathrm{L})$, but the influence did not significant after 8 weeks (42 IU/L).

Table 8. The effect of eating figs on ALT (U/l) for different groups of hamsters after 4 weeks and 8 weeks

\begin{tabular}{llll}
\hline Groups & $\begin{array}{l}\text { Beginning of the } \\
\text { experiment }\end{array}$ & After 4 weeks & After 8 weeks \\
\hline Group 1 & $54.0 \pm 5.2^{\mathrm{aA}}$ & $59.5 \pm 4.1^{\mathrm{aA}}$ & $56.5 \pm 3.2^{\mathrm{aA}}$ \\
Group 2 & $58.3 \pm 4.1^{\mathrm{aA}}$ & $64.0 \pm 1.3^{\mathrm{bB}}$ & $64.3 \pm 2.1^{\mathrm{bB}}$ \\
Group 3 & $59.0 \pm 4.7^{\mathrm{aA}}$ & $52.0 \pm 2.6^{\mathrm{cB}}$ & $44.0 \pm 5.6^{\mathrm{cC}}$ \\
\hline
\end{tabular}

\section{Average \pm standard error}

Averages carrying letters English small (a, b, c) are similar in the same column mean significant differences ( $\mathrm{P}<0.05$ ), averages that carry letters English large (A, B, C) are similar in the same row means no differences significantly $(\mathrm{P}>0.05)$.

Table 9. The effect of eating figs on AST (U/l) for different groups of hamsters after 4 weeks and 8 weeks

\begin{tabular}{llll}
\hline Groups & $\begin{array}{l}\text { Beginning of the } \\
\text { experiment }\end{array}$ & After 4 weeks & After 8 weeks \\
\hline Group 1 & $51.0 \pm 6.2^{\mathrm{aA}}$ & $53.0 \pm 4.1^{\mathrm{aA}}$ & $57.0 \pm 1.3^{\mathrm{aA}}$ \\
Group 2 & $51.0 \pm 2.1^{\mathrm{aA}}$ & $57.0 \pm 2.2^{\mathrm{bB}}$ & $59.0 \pm 2.4^{\mathrm{bB}}$ \\
Group 3 & $49.0 \pm 2.4^{\mathrm{aA}}$ & $43.0 \pm 3.1^{\mathrm{cB}}$ & $42.0 \pm 2.6^{\mathrm{CB}}$ \\
\hline
\end{tabular}

Average \pm standard error

Averages carrying letters English small $(\mathrm{a}, \mathrm{b}, \mathrm{c})$ are similar in the same column mean significant differences $(\mathrm{P}<0.05)$, averages that carry letters English large (A, B, C) are similar in the same row means no differences significantly $(\mathrm{P}>0.05)$.

High activity of the enzyme ALT may be associated with dysfunction of the lining of the heart and hardening of the carotid arteries, it has been studied in the Caucasus on men and women between the ages of 50-75 years to predict the relationship between ALT and the incidence of 
cardiovascular disease and coronary heart disease and the duration of the study 10 years. The study has been involved 1439 cases and proved that there is a relationship between the high activity of the enzyme ALT and coronary heart disease [43].

The current study agreed with other study [44], which aimed to find out antioxidant activity in the extract of figs and their impact on the liver of rats, where has the experience to 24 rat mentioned were divided into 4 groups, the first group control group was given water, and the second group were fed the extract of figs for 6 weeks. After six weeks rats were divided in each group into two groups, each group were injected with through methanol daily dose of $2.37 \mathrm{~g} / \mathrm{kg}$ of the weight of the rat for 4 weeks and the results showed that the group that was injected with methanol only increased the enzyme activity ALT, AST, where the extract figs has a role in the prevention of methanol poisoning, which leads to oxidative damage to the liver.

\section{Conclusion}

This study can conclude that Phenols in dried figs may be important antioxidants as demonstrated by the in vivo antioxidant effect from eating a serving size of figs. Figs can impact heart and atherosclerosis positively. This can be evident by the explored findings of decreasing total cholesterol levels, low-density LDL cholesterol and triglycerides, reduced liver enzymes AST and ALT significantly and increased high-density cholesterol HDL. Further research into the content levels of phenolics should also be done on dried figs, which are popular and represent a healthy alternative to confectionary.

\section{Rreferences}

[1] Egert, S., and Rimbach, G. (2011). Which sources of flavonoids: complex diets or dietary supplements? review. Advances in Nutrition an International Review Journal.

[2] Prakash, A., Rigelhof, F., and Miller, E. (2007).Antioxidant activity.A publication of Medallion labs. Dr. DeVries (ed).

[3] Vayalil, P. (2002). Antioxidant and antimutagenicproperties of aqueous extract of date fruit (phoenixdactylifera). J. Agric. Food Chem. 50: 610- 617.

[4] Rahman, K., (2007). Studies on free radicals, antioxidants and co-factors. J. of Clinical Interventions in Aging 2: 219236.

[5] Crozier, A., Jaganath, I., Marks, S., Saltmarsh, M., and Clifford, M. (2006). Secondary metabolites as dietary components in plant- based food and beverages, Crozier, A., Clifford, M., Ashihara, H, Editors, plant secondary metabolites: occurrence, structure, role in the human diet, Blackwell Publishing, Oxford, 208-230.

[6] John, J., Ziebland, S., Yudkin, P., Roe, L., and Neil, H. (2002). Effects of fruit and vegetable consumption on plasma antioxhdant concentrations and blood pressure: a randomized controlled trial. The Lancet 359: 1969- 1974.
[7] Tuker, G. (2003). Nutritional enhancement of plants. Current Opinion in Biotechnol. 14: 1-5.

[8] Bazzano, L., Ogden, L., Loria, C., Vupputuri, S., Myers, L., and Whelton, P. (2002). Fruit and vegetable intake and risk of cardiovascular disease in US adults: the first national health and nutrition examination survey epidemiologic follow- up study. Am. J. Clin. Nutr. 76: 93- 99.

[9] Slavin, J. L. (2006). Figs: Past, Present and Future. Nutr. Today 41: 180-184.

[10] Sozzi, G. O., Abrajan-Villasenor, M. A., Trinchero, G. D. and Fraschina, A. A. (2005). Postharvest response of 'Brown Turkey' figs (Ficus carica L.) to the inhibition of ethylene perception. J. of the Sci. of Food and Agric. 85: 2503-2508.

[11] Solomon, A., Golubowicz, S., Yablowicz, Z., Grossman, S., Bergman, M. and Gottlieb, H. E. (2006). Antioxidant activities and anthocyanin content of fresh fruits of common fig (Ficus carica L.). J. Agric. Food Chem. 54: 7717-7723.

[12] Trichopoulou, A., Vasilopoulou, E., Georga, K., Soukara, S. and Dilis, V. (2006). Traditional foods: Why and how to sustain them. Trends in Food Sci. \& Technol. 17: 498-504.

[13] Veberic, R., Trobec, M., Herbinger, K., Hofer, M., Grill, D. and Stampar, F. (2005). Phenolic compounds in some apple (Malus domestica Borkh) cultivars of organic and integrated production. J. of the Sci. of Food and Agric. 85: 1687-1694.

[14] Veberic, R., Colaric M. and Stampar, F. (2008). Phenolic acids and flavonoids of fig fruit (Ficus carica L.) in the northern Mediterranean region. Food Chem. 106: 153-157.

[15] Vinson, J., Zubik, L., Bose, P., Samman, N., and Proch, J. (2005). Dried fruits: excellent in vitro and in vivo antioxidants. J. Am. Coll. Nutr. 24: 44-50.

[16] Sinopoulos, A. (2001). The Mediterranean diets: what is so special about the diet of Greece? The scientific evidence.Nutrition, Health and Ageing, 131: 728- 735.

[17] Manach, C., Scalbert, A., Morand, C., Remesy, C., and Jimenez, L. (2004). Polyphenols: food sources and biovaliability. Am. J. Clin. Nutr. 79: 727-747.

[18] Prior, R., Gu, L., Wu, X., Jacob, R., Sotoudeh, G., Kader, A., and Cook, R. (2007). Plasma antioxidant capacity changes following a meal as a measure of the ability of a food to alter in vivo antioxidant status. J. Am. Coll. Nutr. 26: 170181.

[19] Sirisha, N., Sreenivasulu, M., Sangeeta, K., Chetty, C. (2010). Antioxidant Properties of Ficus Species - A Review. International Journal of PharmTech Research, 2, 2174-2182.

[20] Dipersio, P., Kendall, P. and Sofos. J. (2003). Inactivation of Salmonella during drying and storage of apple slices treated with acidic or sodium metabisulfite. J. Food Prot. 12: 22452251.

[21] Singh, R., Murthy, C., and Jayaprakasha, G. (2002).Studies on the antioxidant activity of pomegranate(punicagranatum) peel and seed extract using in vitro models. J. Agric. Food Chem. 50: 81-86.

[22] Cai, Y. Z., Luo, Q., Sun, M., Corke, H. (2004). Antioxidant activity and phenolic compounds of 112 traditional Chinese medicinal plants associated with anticancer. Life Sci. 74: $2157-2184$. 
[23] Escarpa, A. and Gonzalez, M. C. (1998). High-performance liquid chromatography with diode-array detection for the determination of phenolic compounds in peel and pulp from different apple varieties. J. of Chromatography A, 823: 331337.

[24] Auger, C., Caporiccio, B., Landrault, N., Teissedre, P., Laurent, C., and Cros, G. (2002). Red wine phenolic compounds reduce plasma lipids and a polipoprotein B and prevent early aortic atherosclerosis in hypercholesterolemic golden Syrian hamsters (mesocricetusaurratus). J. Nutr. 132: 1207- 1213.

[25] National Research Council, 1985 National Research Council. Guide for the Care and the Use of Laboratory Animals. (1985). Publication Nos. 85-23(rev.). National Institutes of Health, Bethesda, MD.

[26] Reeves, P.G., Nielsen, F.H. and Fahey, G.C. (1993). AIN-93 purified diets for laboratory rodents: final report of the American Institute of Nutrition ad hoc writing committee on the reformulation of the AIN-76A rodent diet. J. Nutr. 123: 1939-1951.

[27] Reeves, G. (1997).Components of the AIN-93 diets as improvements in the AIN-76A diet. J. Nutr. 127: 838S- 841S

[28] AOAC.Official Methods of Analysis of American Official Association of Chemists.(2000). 16 Edn. Washington, DC, USA.

[29] Richmond, N. (1973). Preparation and properties of cholesterol oxidase from on cardia SP. And its application the enzymatic essay of total cholesterol in serum. J. Clinical Chem. 19: 1350- 1356.

[30] Trinder, P.(1969). Enzymatic method of triglycerides. Annals of Clinical Biochem., 6: 24- 27.

[31] Van Horn, L., Annemidy, L., Liu, K., Liao, Y., Ballew, C., King, J., and Stamler, J. (1988). Serum lipid response to a fat modified oat meal- enhanced diet. Preventive Medicine 17: $377-386$

[32] Reitman, S., and Frankel, S. (1957). A colorimetric method for the determination of serum lutamate oxaloacetate and pyruvate transaminase. American J. of Clinical Pathology 28: $56-63$.

[33] Lee, K. W., Kim, Y. J., Kim, D., Lee, H. J. and Lee, C. Y. (2003). Major phenolics in apple and their contribution to the total antioxidant capacity. J. Agric. Food Chem. 51: $6516-6520$
[34] Lattanzio, V. (2003). Bioactive polyphenols: Their role in quality and storability of fruit and vegetables. J. of Applied Botany 77: 128-146.

[35] Vallejo, F., Marin, M., and Tomas- Barberan, F. (2012).Phenolic compound content of fresh and dried figs (FicusCarica L.).Food Chem. 130: 485- 492.

[36] Hakkinen, S., Heinonen, M., Karenlampi, S., Mykkanen, H., Ruuskanen, J. and Torronen, R. (1999). Screening of selected flavonoids and phenolic acids in 19 berries. Food Research International, 32: 345-353.

[37] Yilmaz, Y. and Toledo, T. D. (2004). Major flavonoids in grape seeds and skins: Antioxidant capacity of catechin, epicatechin, and gallic acid. J. Agric. Food Chem. 52: 255260.

[38] Gorinstein, S., Zemser, M., Haruenkit, R., Chuthakorn, R., Grauer, F. and Martin-Belloso, O. (1999). Comparative content of total polyphenols and dietary fiber in tropical fruits and persimmon. J. Nutritional Biochem. 10: 367-371.

[39] Tomas-Barberan, F. A. and Clifford, M. N. (2000). Dietary hydroxybenzoic acid derivatives - nature, occurrence and dietary burden. J. of the Sci. of Food and Agric. 80: 10241032.

[40] Auger, C., Al-Awwadi, N., Bornet, A., Rouanet, J.-M., Gasc, F. and Cros, G. (2004). Catechins and procyanidins in Mediterranean diets. Food Res. International, 37: 233-245.

[41] Moreno, C., Escrig, A., and Calixto, F. (2000). Study of lowdensity lipoproteinoxidizability indexes to antioxidant activity of dietary polyphenols. Nutr. Research 20: 941- 953.

[42] Steinberg, D., Parathasarathy, S., Carew, T. E,. Khoo, J. C. and Witzum, J. L.(1989). Beyond cholesterol; modification of low-density lipoprotein that increases its atherogenicity. New Engl. J. Med. 320:915-924.

[43] Schindhelm, R., Dekker, J., Nijpels, G., Bouter, L., Stehouwer, C., Heine, R., and Diamant, M. (2007). Alanine aminotransferase predicts coronary heart disease events: A 10-year follow-up of the Hoorn Study. J. of Atherosclerosis 191: 391- 396.

[44] Saoudi, M., and Elfeki, A. (2012). Protective role of ficus carica stem extract against hepatic oxidative damageinduced by methanol in male wistar rats. Evid. Based Complement. Alternat. Med. 8: 1-8. 